\title{
The Blush of Modesty or the Blush of Shame? Reading Jane Austen's Blushes
}

\author{
Katie Halsey
}

'Let us not desert one another; we are an injured body'. Even as she rebukes the writers of novels who disown their own creations, the narrator of Jane Austen's Northanger Abbey famously attempts to rehabilitate the reputation of the female-authored novel, commending Cecilia, Camilla and Belinda, and calling for team spirit. (Northanger Abbey, pp.32-33). ${ }^{1}$ Austen rightly recognises an extensive contemporary body of opinion against the novel: 'no species of composition has been so much decried. From pride, ignorance, or fashion, our foes are as many as our readers'. But she also insists that 'our productions have afforded more extensive and unaffected pleasure than those of any other literary corporation in the world' (p.32). Austen reacts in a variety of ways to her contemporaries' diatribes against reading the novel: by attributing a fear of the novel to the idiotic Mr Collins in Pride and Prejudice, for example, she neatly exposes the idiocy of the fear; in Northanger Abbey she legitimises the novel by claiming for it the qualities more commonly attributed to the irreproachable periodical essay; by exposing and regendering stereotypes such as that of the girl led astray by romances in Sanditon, she indicates the gendered absurdity of such stereotypes. Her own sane and rational novels, with their emphasis on the domestic and the everyday, and their small cast of characters and limited social milieu, form a corrective both to the more absurd and melodramatic of her contemporaries' works, and also to the critics and readers who tar all novels with the same brush.

I would like to suggest here that Jane Austen's prose style enacts a similar corrective to notions of the novel's frivolity, demanding the kind of strenuous reading more commonly associated by eighteenth-century moralists with the reading of non-fictional prose. Mary Poovey argues that Austen, like Mary Shelley and Mary Wollstonecraft, was driven by the dictates of propriety, as manifested in the domestic ideology, to use strategies of 'indirection and accommodation', which appear at the level of content and form 'as resolutions blocked at one level of a narrative and then displaced by other subjects that are more amenable to symbolic transformation'. An example is 'Austen's imposition of a romantic resolution on the realistic premise of Pride and Prejudice'. ${ }^{2}$ Throughout this article, I agree with Poovey that Austen employs strategies of indirection that are grounded in conduct-book notions of propriety. Where she sees such strategies as limiting and defensive, however, I argue that they are in fact pleasurable and defiant, forming part of the games of 'Ingenuity' that Austen plays with her readers. 'I do not write for such dull Elves / As have not a great deal of Ingenuity themselves', Austen

\footnotetext{
${ }^{1}$ All references to the works of Jane Austen will appear in the body of the text. The page numbers refer to the following editions: Pride and Prejudice, ed. James Kinsley and Frank W. Bradbrook (Oxford, 1980); Mansfield Park, ed. James Kinsley (Oxford, 1980; repr. 1990); Emma, ed. Ronald Blythe (Harmondsworth, 1985; repr. 1986); Northanger Abbey, ed. John Davie (London, 1971); Persuasion, ed. John Davie (Oxford \& New York, 1971; repr. 1992).

2 Mary Poovey, The Proper Lady and the Woman Writer: Ideology as Style in the Works of Mary Wollstonecraft, Mary Shelley and Jane Austen (Chicago \& London, 1984), p.242.
} 
famously wrote to her sister Cassandra in a letter of 29 July $1813 .^{3}$ Like many of Austen's intertextual jokes (this one appropriates Walter Scott's Marmion ${ }^{4}$ ), this has its serious side. Where Poovey argues that Austen 'attempts to convert the pleasure generated by imaginative engagement into a didactic tool' in the service of conservative morality, ${ }^{5}$ I suggest that, on the level of style, Austen's strategic indirections - which include her characteristic free indirect discourse, her use of allusion and her parodic narrative voice - stem from and create a resistance to the ideologies that her novels' plots appear to endorse. Austen's style, Mary Lascelles suggests, creates a special bond between author and reader, a bond that makes readers complicit in the demands of the narrative voice and excludes those who do not understand that particular relationship: Austen's writing is 'as elliptical and indirect as talk among friends, where intuitive understanding can be counted on' 6

Crucially for my argument, however, the narrative voice also plays tricks on the reader, leading her into false conclusions, and exposing the ways in which convention dictates responses to both literature and life. The questions raised by Austen's style are thus epistemological and moral: her novels demand that her readers question not only what they know, but how they know it. ${ }^{7}$ They require, in Coleridge's memorable phrase, 'hard reading', not just of the novels themselves, but of the conventions and assumptions the novels satirise. ' 'Hard reading' is both playful and strenuous: to take part in the games of the narrative voice a reader has to learn to read extremely carefully. Here, I will discuss one specific narrative strategy: Austen's deployment and reformulation of a narrative convention ubiquitous in the work of her eighteenth-century predecessors: the narrative bond created by a literary character's blush.

\section{Eloquent Blood}

'It might with truth be said that "her eloquent blood spoke through her modest cheeks", writes Henry Austen of his sister, in the 'Biographical Notice' attached to the posthumous edition of Jane Austen's Northanger Abbey and Persuasion (1818). ${ }^{9}$ This part of Henry's idealised portrait adopts and adapts John Donne's lines on Elizabeth Drury: 'We understood / Her by her sight: her pure and eloquent blood / Spoke in her

\footnotetext{
${ }^{3}$ Jane to Cassandra Austen, 29 July 1813, in Jane Austen's Letters, ed. Deirdre Le Faye (Oxford, 1995), p. 202.

${ }^{4}$ Scott's lines are as follows: I do not rhyme to that dull elf / Who cannot image to himself. [Walter Scott, Marmion; or, A Tale of Flodden Field (1808), VI. 38. (London, 1869).

${ }^{5}$ Poovey, p.183.

${ }^{6}$ Mary Lascelles, Jane Austen and her Art (Oxford, 1939; repr. 1974), p.43.

${ }^{7}$ Although it is outside the scope of this article, it is worth noting that Austen's writings thus belong within an eighteenth-century tradition of ethical philosophy that emphasizes the value of sympathy in moral education, most famously articulated in Adam Smith's Theory of Moral Sentiments (1759). It is vital that readers feel with and for Austen's characters in order to benefit from the lessons in interpretation that her heroines learn.

${ }^{8}$ S.T. Coleridge, 'On the Constitution of Church and State', ed. John Colmer, in The Collected Works of Samuel Taylor Coleridge, 16 vols (London, 1976), X, 134.

${ }^{9}$ Henry Austen, 'Biographical Notice of the Author', in Persuasion, ed. John Davie (Oxford \& New York, 1971; repr. 1992), p.3.
} 
cheeks, and so distinctly wrought, / That one might almost say, her body thought' ${ }^{10}$ It is worth noticing that the word 'modest' is Henry's addition, reflecting an unconscious assumption that 'eloquent blood' can 'speak' only in the cheeks of a 'modest' woman. This assumption is not surprising, given the frequency with which the trope of the modestly blushing female appears in eighteenth- and early nineteenth-century writing from conduct books and journals to poetry and novels - and the extent to which the innate ambiguity of the blush tends to be ignored or suppressed. Blushes, both real and figurative, are ever-present in the literature of the eighteenth and early nineteenth centuries, and despite the evidence of contemporary physiologists (who saw anger and shame as the chief causes of blushing), novelists and poets continued to insist on the innate 'modesty' of the feminine blush. In works as different as Samuel Richardson's Pamela (1740), Henry Fielding's Tom Jones (1749), Fanny Burney's Evelina (1778) and Hannah More's Coelebs in Search of a Wife (1808) - all works Jane Austen knew well the ingenuous heroine's blushes mirror both the modesty and superiority of her mind.

Taking as a precedent Milton's Eve, many eighteenth-century writers insist on the perfect innocence of a blush. Since Eve can blush before the Fall of $\operatorname{Man}^{11}$ (i.e. while she is still in a state of perfect, pre-lapsarian innocence), it follows that blushes may be a mark of innocence, rather than guilty knowledge. Following in this tradition, John Gregory's best-selling and influential conduct book A Father's Legacy to His Daughters refuses even to recognise that the blush may hint at more than modesty:

Pedants, who think themselves philosophers, ask why a woman should blush when she is conscious of no crime? It is sufficient answer, that nature has made you to blush when you are guilty of no fault, and has forced us to love you because you do so. - Blushing is so far from being necessarily an attendant on guilt, that it is the usual companion of innocence. $^{12}$

He chooses to ignore the possibility that a blush of guilt (at least on the faces of women like his daughters) could exist. Similarly, the New Lady's Magazine tells its readers, 'shamefacedness carries the very colour of virtue, and that blush which spreads itself over her face, is a mark of her abhorrence of vice'. ${ }^{13}$ Shamefacedness here, paradoxically, is proof that a woman has done nothing shameful; only the innocent can still blush. Novelists of the eighteenth century find this a useful 'truth' to assert. In Burney's Evelina, for example, the heroic Lord Orville rejects the idea that a virtuous young lady could blush for any impure reason: when the foppish Mr Lovel claims that he has 'known so many different causes of a lady's colour, such as flushing, - anger, - mauvaise honte, and so forth, that I never dare decide to which it may be owing', he is swiftly put in his place by the assembled company, and Orville comes to Evelina's defence, taking the true motive of her blush (embarrassment) for granted. ${ }^{14}$ This brief exchange demonstrates a handy novelistic convention: the blush can provide the reader with privileged knowledge

\footnotetext{
${ }^{10}$ John Donne, The Second Anniversarie of the Progres of the Soule, 242-45 (London, 1621).

11 'To the Nuptial Bowre / I led her blushing like the Morn'. (Paradise Lost, viii. 510-11).

${ }^{12}$ John Gregory, A Father's Legacy to his Daughters (1774) (London, 1795), p.38.

${ }^{13}$ Anonymous, 'On Shamefacedness', New Lady's Magazine, 1 (1786), 27.

${ }^{14}$ Frances Burney, Evelina; or, a Young Lady's Entrance into the World (1798), ed. Susan Kubica Howard (Ontario, 2000), p.180.
} 
that characters within the novel may not have. Mr Lovel reads Evelina's complexion wrongly, but, as readers, we cannot do so because we have access to her inner thoughts, rather than only to the surface of her skin. We can therefore judge Evelina's blush correctly.

Blushes, in the modest heroine tradition ${ }^{15}$, do not symbolise only innocence; Mary Wollstonecraft's Female Reader (1789) makes it clear that there is a relationship between blushes and 'mental charms' when it assures young women that 'It is not necessary to speak to display mental charms, the eye will quickly inform us if an active soul resides within; and a blush is far more eloquent than the best turned period'. ${ }^{16}$ In Mary Hays's Memoirs of Emma Courtney (1796), the heroine, a largely autobiographical creation, assures the man she loves that she is 'incapable of dissimulation, the emotions of my mind are ever but too apparent in my expression, ${ }^{17}$. It is for this reason that Emma has to insist that her blushes are 'the blushes of modesty, not of shame'18 (emphasis Hays's); since Harley can judge her emotions by her blushes, it is essential for Emma that he should interpret her blushes as modestly innocent. But it was not only radical women writers like Hays and Wollstonecraft, speaking out for greater sincerity and honesty between the sexes, who believed that the expression on a woman's face revealed her soul. Writers from across the political spectrum present modest and expressively blushing heroines; Hannah More's conduct-book-as-novel, Colebs in Search of a Wife, for example, introduces the exemplary Lucilla Stanley, who demonstrates both her 'mental charms' and 'active soul' through a blush and a speaking silence in the presence of her father and her prospective suitor. The hero, looking for a wife who demonstrates 'the true learning for a lady' ('a knowledge that is rather detected than displayed', ${ }^{19}$ ) is delighted to trace 'her knowledge of the best authors, though she quoted none' from Lucilla's blushes when the subject of ladies learning Latin arises. ${ }^{20}$ Conventionally, modesty, innocence and intelligence can thus all be denoted by a blush, which the informed reader will know how to read.

Within the modest heroine tradition, the blush is assumed to be a guarantee of authentic emotion, a safeguard against feminine deceit. Blushing speaks the language of the heart, a language that the lips may be denied from uttering. The natural rose of a country girl's cheeks is frequently contrasted to the artificial rouge used in the inauthentic world of the fashionable or the depraved (a marker of Sir Walter Elliot's inability to value the authentic is his wish that Lady Russell 'would only wear rouge' [Persuasion, p.203]). While using rouge can counterfeit colour in an elderly, sallow or depraved face, only emotion can make the colour come and go, as it does in the face of the modest heroine, whose blushes cannot be faked. In Evelina, Lord Orville compliments Evelina's natural complexion, by contrasting it to that created by rouge:

\footnotetext{
${ }^{15}$ I am indebted to Ruth Bernard Yeazell for her excellent discussion of this tradition in Fictions of Modesty: Women and Courtship in the English Novel (1991).

${ }^{16}$ Wollstonecraft, 'Preface', The Female Reader (1789), ed. Moira Ferguson (Delmar, N.Y., 1979), pp.xiiixiv.

${ }_{17}^{17}$ Mary Hays, Memoirs of Emma Courtney (1796), ed. Eleanor Ty (Oxford, 1996;), p.80.

${ }^{18}$ ibid.

${ }^{19}$ Hannah More, Cæelebs in Search of a Wife (1808), ed. Mary Waldron (Bristol, 1995), p.218.

${ }^{20}$ ibid, p.218.
} 
the difference of natural and artificial colour, seems to me very easily discerned; that of Nature, is mottled, and varying; that of art, set, and too smooth; it wants that animation, that glow, that indescribable something which, even now that I see it, [in Evelina's face] wholly surpasses all my powers of expression. ${ }^{21}$

Lord Orville rightly reads Evelina's sincerity in her blushes, even though he is not privy to the emotions that prompt her colour. ${ }^{22}$

The natural blush informs a spectator, then, that the young woman is capable of authentic emotion, but it does not always reveal what that emotion might be. In Northanger Abbey, Catherine Morland is unable to read her friend Isabella's blush: after telling Isabella that she does not want to marry her brother, Catherine says, 'you know, we shall still be sisters', referring to Isabella's engagement to James Morland. Austen presents Isabella's reply: "Yes, yes" (with a blush), "there are more ways than one of our being sisters. But where am I wandering to?"' (p.128). Catherine, in her innocence, does not recognise that Isabella's blush denotes the possibility that the two could still 'be sisters' if Catherine were to marry Henry Tilney and Isabella his brother, Captain Tilney. The reader, on the other hand, sees exactly where Isabella is 'wandering to'. In Mansfield Park, too, Sir Thomas, although no innocent, cannot read his niece Fanny's blushes. At the pivotal moment when Sir Thomas tries to ascertain Fanny's motive for rejecting Henry Crawford, he suggests to her that her affections may already be engaged. After this:

He paused and eyed her fixedly. He saw her lips formed into a no, though the sound was inarticulate, but her face was like scarlet. That, however, in so modest a girl might be very compatible with innocence; and chusing at least to appear satisfied, he quickly added, "No, no, I know that is quite out of the question - quite impossible." (MP, p.286)

Sir Thomas concludes that Fanny is not already in love, but the reader knows that her affections are indeed engaged (by the unknowing Edmund); her blush is not of innocence, but of guilt. While Fanny's blush truly tells the language of her heart, her uncle does not speak its language, and so cannot interpret it correctly.

Unlike Sir Thomas, a reader, to whom Fanny's thoughts are usually open, has a better chance of understanding Fanny's blushes. Although the emotions prompting her blushes are not always explicit, we are generally close enough to what Fanny has been feeling or thinking to interpret her colour better than the characters around her. And often, Austen chooses to explain a blush, to do away with the necessity for her readers to interpret it. This device is a staple of eighteenth-century fiction - Evelina, for example, writes of herself that she is 'blushing for her unworthiness', 23 while Emma Courtney writes to Augustus Harley, 'I blush, when I reflect what a weak, wavering, inconsistent, being, I

\footnotetext{
${ }^{21}$ Burney, Evelina, p.181.

${ }^{22}$ Alexander Pope brilliantly exploits this conceit in his satirical commentary on female vanity and consumer society, The Rape of the Lock (1712-14). Belinda 'sees by degrees a purer blush arise' only through 'cosmetic powers' as she 'arms' herself at her dressing table; ironically Belinda's 'purer blush' is painted on and hides the impurity of thought denoted by her natural blushes. (The Rape of the Lock, I, 143 \& 124).

${ }^{23}$ Burney, Evelina, p.460.
} 
must lately have appeared to you'. ${ }^{24}$ The blushes are both straightforward; we know that it is a feeling of unworthiness that brings the colour to Evelina's cheeks, and a sense of shame to Emma's. The convenience of the blush as a signal that allows the narrator and the reader to share privileged knowledge about the emotions that have caused the blush helps explain its popularity as a novelistic device, and thus its ubiquity in the eighteenthcentury novel.

By the time Austen published her first novel in 1811, the innocent blush, demonstrating the transparency, honesty and modesty of a heroine, had long been established as a convenient literary convention, or shorthand, by both eighteenth-century moral writers and novelists, allowing readers to believe in a privileged narrative bond that encouraged them to read the modest heroine' character correctly. But there of course exists, more commonly in poetry, but also in novels, an alternative literary tradition, that recognises, as Yeazell puts it, 'how equivocally the blood could speak'. ${ }^{25}$ Despite the volumes of insistent rhetoric arguing for the innate innocence of a woman's blush, in fact a blush can represent knowledge as well as innocence. Christopher Ricks suggests that the blush that embodies 'paradoxes about innocence and guilt' has a particular valence during the nineteenth century, and he is certainly right to make this claim. ${ }^{26}$ These paradoxes also appear much earlier. We find in Jonathan Swift's 'Cadenus and Vanessa' (1713), for example, the line: 'They blush because they understand', ${ }^{27}$ an explicit reference to the sexual knowledge implied by a blush. This line is later quoted in Richardson's Pamela as a comment on the aristocratic ladies' abilities to understand a sexual innuendo:

'...Who, that sees her fingers, believes not, that they were made to touch any key?' He laughed out, and, 'O, parson!' added he, 'tis well you are by, or I would have provoked a blush from the ladies'. 'I hope not, Sir Simon', said Mrs Jones; a man of your politeness would not say any thing that would make ladies blush'. 'No, not for the world', replied he; 'but if I had, it would have been, as the poet says,

They blush, because they understand' ${ }^{28}$

Although throughout the novel Richardson insists that his heroine Pamela's blushes remain pure, thus negating the insights about knowing blushing inherent in this extract, a novel without a conservative moral agenda, such as John Cleland's Fanny Hill (1748-9) can afford to explore more fully the blush's equivocations, as when the eponymous heroine makes the transition from innocence to sexual experience. During her first sexual encounter, Fanny, aroused by the caresses of the prostitute Phoebe, comments that 'even my glowing blushes expressed more desire than modesty'. ${ }^{29}$ What should be the signal of

\footnotetext{
${ }^{24}$ Hays, Emma Courtney, p.118.

${ }^{25}$ Ruth Bernard Yeazell, Fictions of Modesty: Women and Courtship in the English Novel (Chicago \& London, 1991), p.67.

${ }^{26}$ Christopher Ricks, Keats and Embarrassment (Oxford, 1974), p.4.

${ }^{27}$ Jonathan Swift, Cadenus and Vanessa: A Poem (London, 1726).

${ }^{28}$ Samuel Richardson, Pamela; or, Virtue Rewarded (1740), ed. Margaret A. Doody (London, 1985), p.332.

29 John Cleland, Fanny Hill; or, Memoirs of a Woman of Pleasure (1748-49), ed. Peter Wagner (Harmondsworth, 1985), p.50.
} 
her modesty (that Fanny herself knows this is neatly demonstrated by the word 'even') is thus transformed into the symbol of her awakened sexuality.

Like Cleland, John Keats (for whom, as Ricks has ably pointed out, blushes have both a sensuous and serious importance) plays on the potentially salacious knowingness of the blush:

O blush not so! O blush not so! /Or I shall think you knowing; / And if you smile the blushing while, Then Maidenheads are going // There's a blush for want, and a blush for shan't, / And a blush for having done it; / There's a blush for thought, and a blush for naught/ And a blush for just begun it. ${ }^{30}$

The overabundance of blushes in this brief ballad, coupled with the innuendo in the repeated 'it' hardly need critical exegesis. Keats characterises 'O blush not so!' as an 'old song, ${ }^{31}$, and there is no doubt that it takes its place in a tradition of writing that plays up the links between women's blushing and sexual knowledge. This link between blushing and sexual knowledge, or, more accurately, knowingness, forms another kind of narrative bond between narrator and reader; the narrator's representations of the blush in these cases acting rather like a wink to those in the know, a laughing complicity that assumes a reader who 'gets' the innuendo.

The conventions of both the modest and the knowing blush depend, therefore, on a reader's complicity with the narrator; an acceptance of a particular set of assumptions that direct us, without telling us, to an assessment of the blush's meaning. In Tristram Shandy (1759-66), Laurence Sterne exposes and undercuts this convention, laying bare the hidden strategy that allows the reader to interpret blushes correctly:

- You shall see the very place, Madam; said my uncle Toby. Mrs. Wadman blush'd look'd towards the door - turn'd pale - blush'd slightly again - recovered her natural colour - blush'd worse than ever; which for the sake of the unlearned reader, I translate thus -

' $L-d$ ! I cannot look at it - What would the world say if I look'd at it? I should drop down, if I look'd at it - I wish I could look at it - There can be no sin in looking at it. I will look at it ${ }^{32}$

Deliberately 'translating' the blush for the 'unlearned reader', Tristram plays with the convention that allows readers to imagine that they translate blushes for themselves, pointing out the author's or narrator's place in manipulating our interpretations.

Tristram's 'translation' points too to the knowingness of the Widow Wadman's blush; she blushes, not because her thoughts are pure (as Evelina would), but because they are not. The 'it' that she so desires to see is the wound in Uncle Toby's groin. Far from

\footnotetext{
${ }^{30}$ John Keats to John Reynolds, 31 January 1818, in The Letters of John Keats 18141821, ed. Hyder Edward Rollins (Cambridge, Ma., 1958), I, 219-20.

${ }^{31}$ Ibid.

${ }^{32}$ Laurence Sterne, The Life and Opinions of Tristram Shandy, Gentleman (1759-66), ed. Tim Parnell (London, 2000), p.524.
} 
being 'a mark of her abhorrence of vice', as the New Lady's Magazine would have it, her blush, like those of Fanny Hill and the women of Keats's poem, is the complicated mark of her curiosity, shame and knowledge. Sterne makes this explicit to his readers.

\section{Dull Elves and Ingenuity}

Austen, who read and knew Sterne, quoting A Sentimental Journey (1768) in her Mansfield Park, draws on both traditions of writing: that of the transparently honest blush and that of the slyly knowing one. Like Sterne, she is interested in the narrative possibilities of an exploitation of the device of the blush-as-narrative-bond. Her innovation is stylistic: using free indirect discourse to exploit conventional expectations of what blushes should mean, the narrative voice misleads readers into misinterpretations or, to use Austen's own term, 'blunders' (Emma, p.344).

Austen is not averse to using the blush in a fairly straightforward way. Mr Knightley, for example, on hearing of Harriet's refusal of Robert Martin, 'actually looked red with surprize [sic] and displeasure' (Emma, p.87). In the early Catharine; or, The Bower, the eponymous heroine enters a ball, with 'a glow of mingled chearfulness [sic] and confusion on her cheeks' ( $S W$, p.209), while her aunt is described as 'colouring with anger and astonishment' (p.210). Later, Catharine, too, finds herself 'blushing with anger at her own folly' (p.221). The emotions - surprise, displeasure, cheerfulness and confusion, anger and astonishment - are all clearly laid out for the reader to see. In Mansfield Park, Fanny Price's 'soft skin, [...] so frequently tinged with a blush' (p.207) does not always need readerly interpretation, for we are often told why she blushes. We hear of her 'colouring at such praise' (p.22), and colouring with anger (p.78). On being pressed to take the part of Cottager's Wife, Fanny grows 'more and more red from excessive agitation' (p.132), and, having reprimanded Henry Crawford later in the novel, she 'trembled and blushed at her own daring' (p.204). Talking to William, her cheeks are 'in a glow of indignation' when she hears that the Gregory girls will not speak to him (p.225). Other characters - Sir Thomas, Henry, Mary, even Edmund - misinterpret Fanny's blushes, but even when we do not have an explicit guide to Fanny's emotions, we learn not to misread her because of their mistakes. Unlike Mary Crawford (who imagines Fanny's colour denotes a liking for Mary's brother, and thus ascribes her blushes to a knowingness Fanny certainly does not possess), we begin to understand what a modest girl's blushes really mean from our proximity to a truly modest heroine. We are thus taught through our own superior degree of knowledge over the other characters, what proper responses should be, and how misreading and misunderstanding can come about. Mary Crawford reads Fanny's skin wrongly; she also consistently responds wrongly to moral dilemmas. Because of our special bond with the narrator, we are able to recognise and learn to condemn Mary's responses to both skin and situations.

In Persuasion, however, Austen undercuts her own use of the blush-as-narrative-bond. Anne, having listened to talk of the connection between the Crofts and Mr Wentworth, the curate of Monkford, walks out 'to seek the comfort of cool air for her flushed cheeks', saying to herself, 'a few months more, and he, perhaps may be walking here' (p.29). The chapter ends immediately, and straight after the chapter break, the narrative voice briskly 
explains, ' $\mathrm{He}$ was not Mr. Wentworth, the former curate of Monkford, however suspicious appearances may be, but a captain Frederick Wentworth, his brother' (p.29). Here, the narrator firmly points out that we should not assume that we can read Anne's blush or her secret thoughts. If we do, we will draw the wrong conclusions.

In Emma, Austen more consistently exploits and subverts the special relationship with the narrator as seen through the device of the blush. Emma Woodhouse, the 'imaginist' who enjoys creating the narratives of other people's lives, repeatedly misinterprets the blushes of Jane Fairfax and, to a lesser degree, those of Harriet Smith. Harriet's blushes are initially fairly transparent (correctly, and conventionally, the ingenue smiles and blushes each time Emma speaks to her of Mr Elton's supposed regard, she blushes as she sits for her picture, her cheeks glow as she reads Robert Martin's declaration of love, and she blushes with shame as she destroys her treasured mementos of Mr Elton). However, as her experience of love and friendship increases, her complexion becomes harder for Emma to read. When others talk of Frank Churchill, and Harriet's countenance remains unmoved, Emma ascribes this to Harriet's improved strength of mind. Harriet, who habitually blushes when she has even the smallest thing to hide, does not blush, which ought to inform Emma of her indifference to Frank, but Emma refuses to attend to the signs. Even when Harriet colours in astonishment at the idea that she might care for $\mathrm{Mr}$ Churchill, crying, 'You do not think I care about Mr Frank Churchill', Emma interprets Harriet's blushes as mortification and her sincerity as fortitude (Emma, p.395). Emma does not remain long in error, for she and Harriet soon understand one another. Her selfdeception over the history she creates for Jane Fairfax is much more long-standing.

Watching Jane after she has received the anonymous gift of the pianoforte (which is supposed by most of Highbury to have come from Miss Fairfax's guardian, Colonel Campbell, but which Emma suspects to be a love-offering from Mr Dixon), Emma interprets Miss Fairfax's 'blush of consciousness with which congratulations were received' as 'a blush of guilt which accompanied the name of "my excellent friend Col. Campbell"' (p.229). Emma is right to discern both a blush of consciousness (Jane later acknowledges how much she has hated having to tell lies) and a blush of guilt (for she knows the piano has come from Frank Churchill, and allowing others to believe it is from Colonel Campbell is a sin of omission if not of commission), but the narrative she creates from these blushes is entirely inaccurate.

The next day, Emma sees Jane Fairfax blush again, a 'deep blush of consciousness' (p.249) when Frank Churchill tells her that a piece of music he picks up was danced at Weymouth. Emma immediately fits this blush into the imaginary love affair she has created between Miss Fairfax and Mr Dixon, reflecting that the 'smile of secret delight' that accompanies the blush of consciousness is the result of her 'very reprehensible feelings' (p.249) towards her friend's husband. Frank Churchill, a master of deceit, recognises and exploits the ways in which a blush can be misinterpreted - not only does he encourage Emma in her self-deception over the two blushes above, he also suggests to Emma that he will impudently admire the 'Irish fashion' of Jane's curls, 'and [Emma] shall see how she takes it; whether she colours' (p.231). Frank thus creates a screen for himself. If Jane blushes at something he says to her, or if her face reveals her feelings by 
a blush, he has provided them both with an excuse for it. He knows that the eloquent blood in a girl's cheeks can be made to tell lies. Emma, on the other hand, has far too much confidence in her ability to read the faces of others, and is keen to see whether Jane does blush. She is therefore chagrined when she discovers that Frank has put himself in her line of vision, because she sees this as a barrier to her interpretation of Jane's motivations.

Later, during the dinner at Hartfield, Jane Fairfax blushes as she explains her desire to walk to the post office, and again when Mr John Knightley hopes that she will soon be surrounded by her dearest connections. Those around her imagine she innocently thinks of her friends the Campbells and Dixons; it later transpires that she must have been thinking of Frank. Emma, though, ascribes Jane's 'glow both of complexion and spirits' (p.298) to the receipt of an imaginary love-letter from Ireland, correctly reading both discomfort and pleasure in her blushes, but misreading the circumstances behind them.

Contrastingly, Mr Knightley reads Jane's blushes more perceptively than Emma, recognising, in the children's game of letters, that the 'blush on Jane's cheek' gives the word blunder 'a meaning not otherwise ostensible' (p.344). Almost immediately afterwards, Frank pushes the word Dixon towards Jane, who is 'evidently displeased', and 'blushed more deeply than he [Mr Knightley] had ever perceived her' (p.345). Mr Knightley, a better reader of complexions than Emma, does not leap to the conclusion that Jane is in love with Mr Dixon. Instead, he continues to suspect Frank of 'some inclination to trifle with Jane Fairfax' (p.340), and tries to warn Emma of the 'symptoms of attachment between them' (p.346). Once the whole story of the engagement has come out, Mrs Weston, too, can understand Jane's blushes, telling Emma, 'she then began to speak of you, and of the great kindness you had shown her during her illness; and with a blush which showed me how it was all connected, desired me, whenever I had an opportunity, to thank you - I could not thank you too much - for every wish and every endeavour to do her good' (p.408). Mrs Weston correctly interprets the 'blush that showed how it was all connected' as an acknowledgement of Jane's jealousy of Emma. Blushes may well show how things are connected; as Emma (and with her, a reader) finds out, they may also lead one to make connections that are not there. With Emma, as readers, we are swept along in the narrative that she has created, and, with Emma, we learn that the blush can be deceptive. What we do not realise, of course, on a first reading of Emma, is how much of the narrative of Jane Fairfax's blushes is in Emma's imagination; a story created, not by the narrator, but by Emma. Because we see the action of the novel so consistently from Emma's viewpoint, and because her tones are so frequently embedded within the narrative voice, we do not know at first when Emma is wrong. We cannot, in fact, know on a first reading that the privileged knowledge we assume we have is faulty.

It is not surprising that we should assume that we can read and interpret blushes correctly in Emma, because our interpretation of Emma's own blushes is guided so that we do understand them. We witness Emma stopping 'to blush and laugh at her own relapse' (p.156), when she momentarily lapses back into matchmaking. We are able to interpret her 'little start, and a blush' at the news of Mr Elton's engagement (p.186) as the result of 
surprise and embarrassment at the memory of his ill-fated proposal to her. We understand (better, perhaps, than Emma does) the 'faint blush' with which Emma notices the 'warmth' of Mr Knightley's interest in Jane Fairfax as that of consciousness of Mrs Weston's belief in his tendresse for her, and unconscious dislike of the idea that anyone else could be of romantic interest to Mr Knightley (p.287). At the ball at the Crown, when Mr Elton refuses to dance with Harriet, Emma's 'heart was in a glow, and she feared her face might be as hot' (p.325), and a reader recognises Emma's anger as the emotion prompting the heat of her face. With her; we feel that she deserves the mortification of being 'under a continual blush all the rest of [her] life' over the 'senseless tricks' she plays to bring Harriet and Mr Elton together (p.335), and we both recognise and feel with Emma when she 'recollected, blushed, was sorry' (p.367) at Mr Knightley's reproach to her after the Box Hill incident. Similarly, we understand her feelings as her colour is heightened in front of Mr Knightley by the unjust praise her father bestows upon her attentiveness to the Bateses (p.377). Once Emma knows the secret of Frank and Jane Fairfax's engagement, she 'could not speak the name of Dixon without a little blush' (p.390), a blush that demonstrates her shame at the tissue of nonsense she created, and later, she is obliged, when talking to Frank, to blush and forbid the name being pronounced in her hearing (p.458). Her 'glowing cheeks' as $\mathrm{Mr}$ Knightley tells her that he already knows of the engagement suggest to Mr Knightley that she may be suffering from love for Frank, but we are explicitly told that 'it occurred to her that he might have called at Mrs Goddard's in his way' (p.413) - the glow, we collect, comes from a fear that he may have seen Harriet. Later, Emma has a 'blush of sensibility on Harriet's account', for which 'she could not give any sincere explanation [to Mr Knightley]', but the reader knows that Emma's blush conceals Harriet's liking for Mr Knightley as well as Emma's guilt at being the one preferred (p.430). Having trusted the narrator's accounts of Emma's blushes, we think we are in a position to trust her account of others' blushes.

Yet Jane Fairfax's blushes show that the complexion can be misread, not only by characters within the novel, but by a reader. Like the Widow Wadman's blush, and Anne Elliot's glowing cheeks, the history of Jane Fairfax exposes the way the blush is used as a fictional device, and challenges the assumptions that we make about our ability to interpret novelistic codes. It teaches us, in other words, about the way we read, the assumptions we make as we are amassing knowledge. When Mr Darcy and George Wickham first come face to face in Pride and Prejudice, both change colour: 'one looked white, the other red'. Elizabeth, 'all astonishment at the effect of the meeting', longs to know the meaning of it. 'It was impossible to imagine; it was impossible not to long to know' (p.64). Like Emma, Elizabeth desires to interpret complexions, and it is significant that her desire is couched in terms of desiring knowledge. Like Emma, Elizabeth is swiftly drawn in to believe what is not true when she hears Wickham's tale; her search for knowledge has gone awry. It is not only Elizabeth, Mary Ann O'Farrell suggests, who may misread what the complexions mean: 'correct assignment of colors [sic] to characters (correct reading of somatic signs) has sometimes proven difficult for readers of this passage, especially, perhaps, for first-time readers; [...] one need not know at this point in the novel that Darcy's is the righteous, angry blanching, Wickham's the 
embarrassed blush' ${ }^{33}$ One certainly need not know that it is Darcy who turns white and Wickham red; indeed, an equally plausible explanation is that Darcy's is the red of anger, and Wickham's the white of fear. Or, as Elizabeth might think, Darcy is white from unjustified resentment, and Wickham red from justified anger. Neither Elizabeth nor the reader, in other words, should find a somatic sign in either men or women entirely trustworthy; knowledge of character is a tricky business, and making mistakes is an essential part of acquiring knowledge. It is particularly difficult for a reader to make the necessary judgements, especially when the narrator deliberately refuses to explain the reason for a blush, as Austen does here. She uses the same trick, teasingly, when she describes Mr Knightley blushing after being accused by Emma and Mrs Weston of a liking for Jane Fairfax. The blush is deliberately left ambiguous: 'Mr Knightley was hard at work upon the lower buttons of his thick leather gaiters, and either the exertion of getting them together, or some other cause, brought the colour into his face' (p.288; emphasis mine). The device is used again in Persuasion, when Anne realises she has been misattributing Lady Russell's fixed regard on the window curtains to the sight of Captain Wentworth: 'Anne sighed and blushed and smiled, in pity and disdain, either at her friend or herself' (Persuasion, p.170). The reader cannot know whether $\mathrm{Mr}$ Knightley's colour results from his exertion or his secret thoughts, and we are not allowed to know whether Anne blushes for herself or for Lady Russell. We are thus faced with the necessity for interpretation, and with the limits of our knowledge.

The blush, then, in Austen's writing can be both a transparent indicator of a character's feelings, and an agent of misdirection. Austen is quite capable of teasingly using it in both ways within a single novel. The characters in Pride and Prejudice, Persuasion, Mansfield Park and Emma tend to think that a blush can always be read without difficulty, failing to realise that, when eloquent blood speaks in a person's cheeks, it is worth listening very carefully to understand what it is really saying. Provided with greater evidence of what is happening below the surface of the skin, a reader initially learns to think that her degree of knowledge is superior to that of the characters in the novel; she feels a bond with the narrative voice from which these characters are excluded. However, as we see in Emma, a reader must then learn that the very existence of such a bond between narrator and reader is problematic. Katherine Mansfield identifies the appeal of Austen's novels as lying in the fact that 'every admirer of the novels cherishes the happy thought that he alone - reading between the lines - has become the secret friend of their author'. ${ }^{34}$ Mansfield is only half right. Among her other teasing interpretative games with the reader, Austen's use of blushes in Emma teaches us that even 'reading between the lines' and becoming the 'secret friend' of the author only brings us face to face with our own interpretative

\footnotetext{
${ }^{33}$ Mary Ann O' Farrell, Telling Complexions: The Nineteenth-Century English Novel and the Blush (Durham and London: Duke University Press, 1997), p.18.

${ }^{34}$ Katherine Mansfield, Novels and Novelists (London: Constable \& Co, 1930), p.304.
} 